\title{
IMPLEMENTASI METODE ITERATIVE INCREMENTALPADA SISTEM ADMINISTRASI ORGANISASI GERAKAN ANTASARI SEDEKAH JAKARTA
}

\author{
Wanda Novianti ${ }^{1}$, Rini Amalia ${ }^{2}$, Fitria Sari Hasanusi ${ }^{3}$ \\ Program Studi Teknik Informatika, Fakultas Teknik dan Ilmu Komputer, \\ Universitas Indraprasta PGRI \\ Jalan Raya Tengah No. 80, Kelurahan Gedong, Pasar Rebo, Jakarta Timur \\ wanda1998nov@gmail.com¹, reen.amaleea@gmail.com², hasanfitria26@gmail.com³
}

\begin{abstract}
Abstrak
Gerakan Antasari Sedekah merupakan organisasi yang bergerak pada beberapa aspek yang berfocus di aspek sosial dan aspek agama yang dekat dengan kehidupan sehari-hari khususnya ke donasi. Sistem pengolahan administrasi yang sedang berjalan pada organisasi. Gerakan Antasari Sedekah masih manual mengakibatkan ketidakefektifan dan ketidakakuratan data yang tersimpan, untuk itu dirancanglah sebuah sistem terkomputerisasi berbasis desktop untuk mempermudah kinerja pengurus organisasi Gerakan Antasari Sedekah dalam pengelolaan data donasi, data donatur, dan data kegiatan penyaluran donasi. Selain mempermudah kinerja, sistem administrasi ini dirancang dengan tujuan untuk mengamankan data-data ke dalam sebuah sistem database untuk menghindari kerusakan atau kehilangan data. Dalam perancangan sistem ini digunakan metode pengembangan sistem adalah metode iterative incremental, dimana aplikasi dibangun melalui empat tahapan yaitu analisa, desain, implementasi, dan pengujian, serta beberapa tahapan penambahan atau inkremental yang disesuaikan dengan kebutuhan user. Memiliki user interface yang mudah dipahami oleh user yang dihasilkan dari beberapa tahapan metode iterative incremental dan berbasis desktop, menjadikan sistem administrasi ini mudah digunakan oleh user dan sesuai dengan kebutuhan user.
\end{abstract}

Kata Kunci: donasi, donatur, iterative incremental, administrasi

\begin{abstract}
Gerakan Antasari Sedekah is an organization that focuses on several aspects that focus on social and religious aspects that are close to daily life, especially donations. Administrative processing system that is running in the organization. Gerakan Antasari Sedekah is still manual resulting in ineffectiveness and inaccuracy of the stored data, for this reason a desktop-based computerized system was designed to facilitate the performance of Gerakan Antasari Sedekah organizational management in managing donation data, donor data, and donation distribution activity data. In addition to simplifying performance, this administration system is designed with the aim of securing data into a database system to avoid data damage or loss. In designing this system, the system development method is iterative incremental method, where the application is built through four stages, namely analysis, design, implementation, and testing, as well as several additional or incremental stages that are tailored to user needs. It has a user interface that is easy to understand by users resulting from several stages of iterative incremental and desktop-based methods, making this administration system easy to use by users and according to user needs.
\end{abstract}

Keywords:donation, donor, iterative incremental, administration

\section{PENDAHULUAN}

Perkembangan teknologi informasi yang berkembang pesat saat ini semakin diperlukan untuk melakukan peningkatan pelayanan terhadap pengolahan data atau administrasi yang lebih cepat dan akurat. Menurut Silalahi (dalam Hamali \& Budihastuti, 2019), administrasi dalam arti sempit merupakan penyusunan dan pencatatan data dan informasi secara sistematis dengan maksud untuk menyediakan keterangan serta memudahkan memperolehnya kembali secara keseluruhan dan dalam hubungannya satu sama lain.

Dimana sistem yang masih manual tersebut cukup menghambat roda organisasi karena sistem manual yang digunakan sering menyebabkan ketidakakuratan data dan keterlambatan laporan. Oleh karena itu, peneliti berupaya untuk membuat suatu perancangan sistem administrasi yang diharapkan dapat membantu organisasi Gerakan Antasari Sedekah dalam pengelolaan sedekah 
menjadi terkomputerisasi, efektif, efisiensi, dan akurat, sehingga masyarakat memiliki rasa kepercayaan yang lebih terhadap penerimaan, pengolahan, dan penyaluran sedekah.

Dalam penelitian ini, peneliti melakukan analisa terhadap sistem yang berjalan dari pendataan donatur, penerimaan donasi, hingga penyaluran donasi. Hal tersebut bertujuan untuk mendukung perancangan sistem administrasi yang terkomputerisasi yang akan dirancang oleh peneliti. Dengan adanya penerapan teknologi, maka akan mempermudah pengolahan data-data dan terjaminnya keamanan data.

\section{PENELITIAN RELEVAN}

Penelitian oleh Pela Estiana yang berjudul Perancangan Sistem Informasi Pengolahan Data Sumbangan Donatur pada Forum Kalijambe Foundation (FKF) di Desa Kalijambe, Tegal dari Universitas Indraprasta PGRI tahun 2018. Hasil penelitian ini menjadi relevansi dalam penelitian yang dilakukan peneliti.Hubungan dari penelitian ini dengan yang dilakukan peneliti adalah mengenai pembahasan sistem pengolahan donasi.Sedangkan perbedaan yang didapat terletak pada metode pengembangan data, dimana penelitian sebelumnya menggunakan metode waterfall.

Penelitian oleh Ocktia Dwi Rahayu yang berjudul Perancangan Sistem Administrasi Zakat, Infaq, dan Shodaqoh (ZIS) pada Lembaga Amil Zakat Nahwa Mur Cibinong Bogor Berbasis Java dari Universitas Indraprasta PGRI tahun 2018. Hasil penelitian ini menjadi menjadi relevansi dalam penelitian yang dilakukan peneliti.Hubungan dari penelitian ini dengan yang dilakukan peneliti adalah mengenai pembahasan sistem administrasi.Sedangkan perbedaan yang didapat terletak pada pengolahan data yang dilakukan, dimana penelitian sebelumnya membuat sebuah sistem menyeluruh mengenai Zakat, Infaq, dan Shodaqoh (ZIS).

Penelitian oleh Ahmad Taufik Hidayat dkk yang berjudul Pengembangan Aplikasi Android "Dikampus" Untuk Manajemen Warung dan Pesanan Menggunakan Metode IterativeIncremental dari Universitas Telkom tahun 2019.Hasil dari penelitian ini menjadi relevansi dalam penelitian yang dilakukan peneliti.Hubungan dari penelitian ini dengan yang dilakukan peneliti adalah mengenai pembahasan metode iterative incremental.Sedangkan perbedaan yang didapat terletak pada basis pembuatan sistem, dimana penelitian sebelumnya menggunakan basis Android.

Penelitian oleh Yuris Sucio Perestroika dkk yang berjudul Pengembangan Sistem Informasi Penggalangan Donasi pada Yayasan GN-TOA Kabupaten Lumajang dari Universitas Brawijaya tahun 2018.Hasil dari penelitian ini menjadi relevansi dalam penelitian yang dilakukan peneliti.Hubungan dari penelitian ini dengan yang dilakukan peneliti adalah mengenai pembahasan sistem pengolahan donasi.Sedangkan perbedaan yang didapat terletak pada basis sistem yang digunakan, dimana penelitian sebelumnya menggunakan basis website.

\section{METODE PENELITIAN}

\section{Metode Pengumpulan Data}

1. Studi Lapangan

a. Observasi

Dalam hal ini peneliti melakukan penelitian langsung terkait kondisi sistem yang berjalan pada organisasi Gerakan Antasari Sedekah.Pengamatan dilakukan mulai dari donatur yang melakukan donasi, pengolahan donasi, sampai bagaimana donasi disalurkan kepada masyarakat yang membutuhkan.

b. Wawancara

Kegiatan wawancara dilakukan untuk mndukung observasi yang telah dilakukan peneliti. Melengkapi data yang telah didapatkan dengan melakukan sesi tanya jawab dengan pengurus organisasi Gerakan Antasari Sedekah, memastikan bahwa sistem yang akan dibangun adalah sistem yang dibutuhkan dan sesuai.

2. Studi Kepustakaan

Peneliti melakukan studi pustaka sebagai bahan tambahan untuk melengkapi kekurangankekurangan data yang diperoleh dari observasi dan wawancara.Pengumpulan data dengan studi pustaka mengambil sumber-sumber data melalui studi pustaka seperti buku-buku dari perpustakaan, mencari informasi dari jurnal dan artikel dari internet, serta peneliti mempelajari, menyimak, dan mengambil kesimpulan dari data dan informasi yang berhubungan dengan permasalahan yang diteliti. 


\section{Metode Pengembangan Sistem}

Perancangan sistem dilakukan untuk menghasilkan sistem yang sesuai yang dibutuhkan pengguna.Untuk menyempurnakan hasil penelitian ini, adapun langkah-langkah dalam perancangan sistem dengan menggunakan metode terstruktur dengan paradigma System Development Life Cycle (SDLC) yaitu dengan model iteratif inkremental (iterative incremental). Model iteratif (iterative model) adalah sebuah SDLC yang mengombinasikan atau menggabungkan proses-proses pada model waterfall dan iteratif pada model prototipe.Model iteratif ini dibuat untuk membenahi kelemahan dari model waterfall yang tidak mengakomodasi iterasi dan membenahi kelemahan dari model prototipe yang prosesnya terlalu pendek.

\section{HASIL DAN PEMBAHASAN}

Analisis Permasalahan

Dari analisa yang telah dilakukan ditemukan perancangan sistem yang akan dilakukan sebagai berikut.

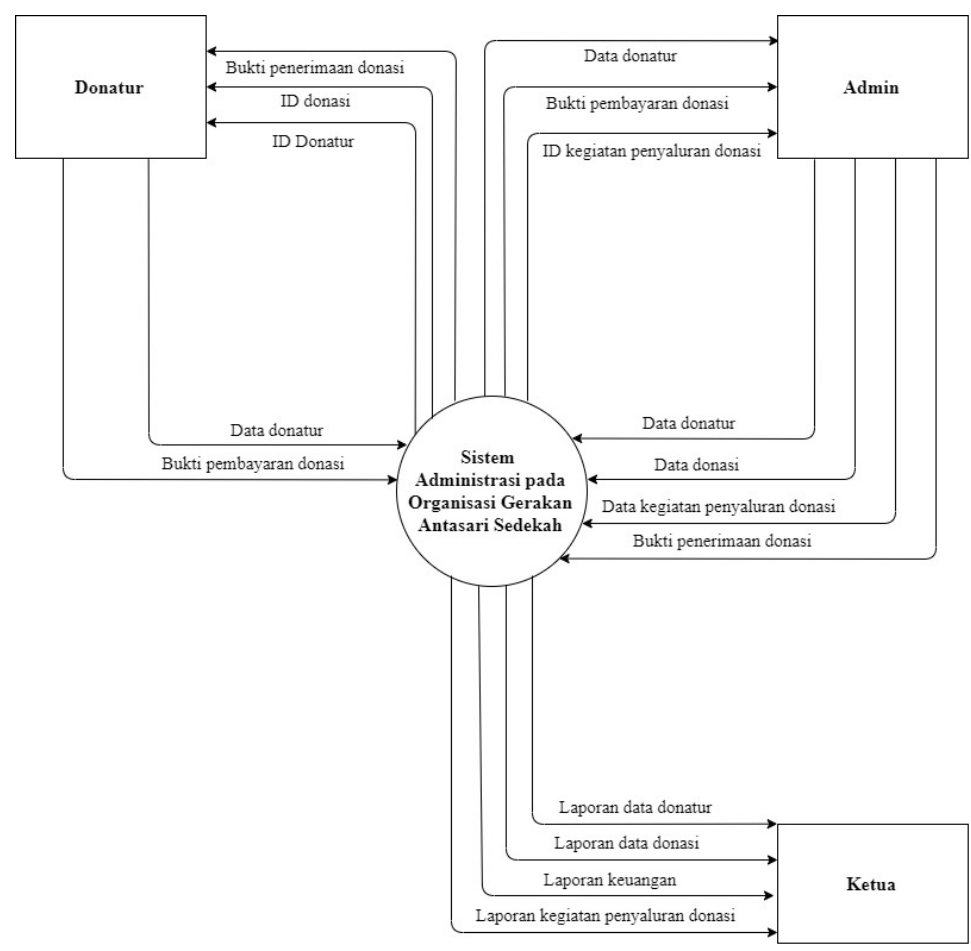

Gambar 1. Diagram Konteks Sistem yang Diusulkan 
Jurnal Riset dan Aplikasi Mahasiswa Informatika (JRAMI)

Vol QZ No Q3 Tahun 202I

e-ISSN :2715-8756
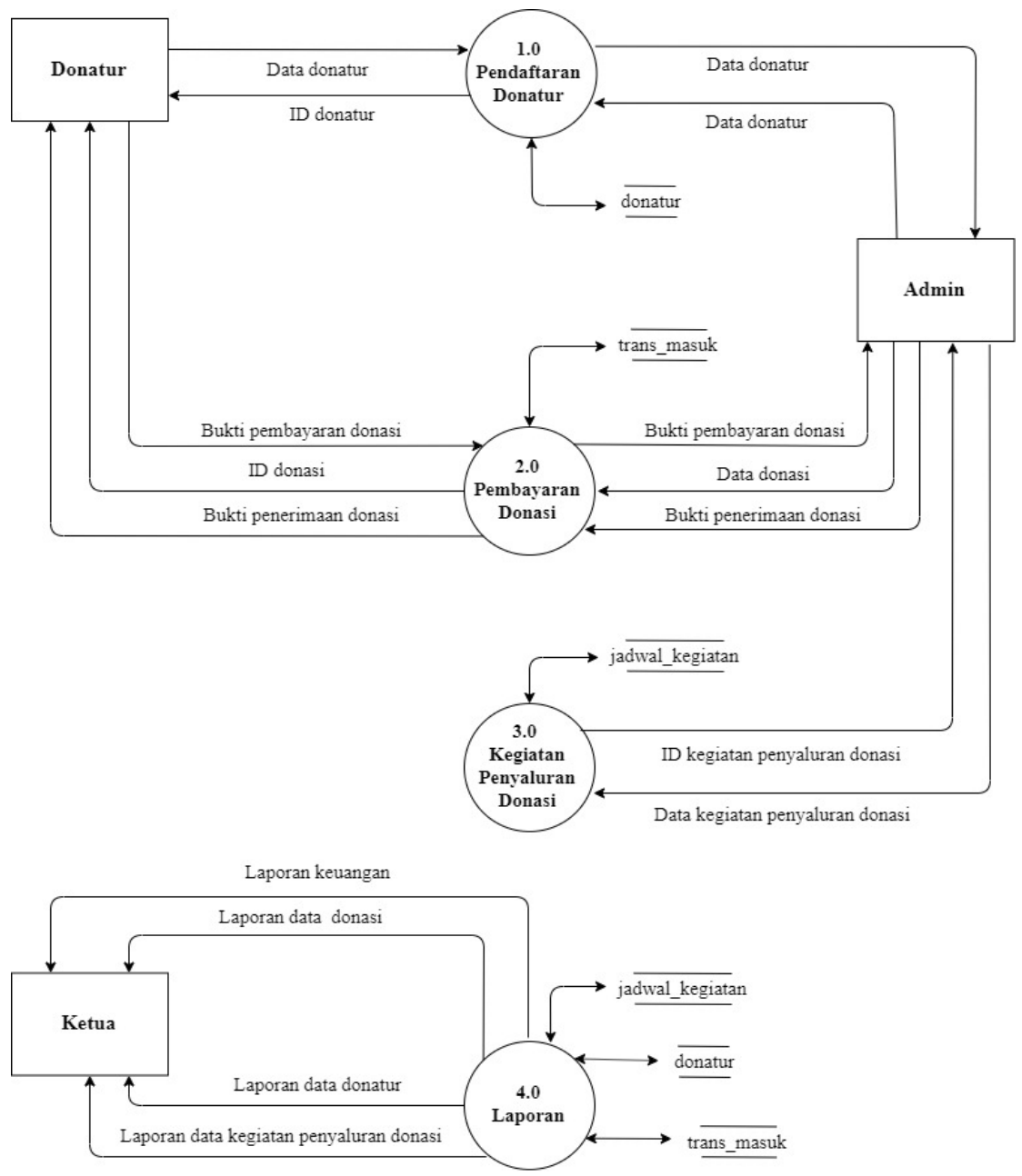

Gambar 2. Diagram Nol Sistem yang Diusulkan

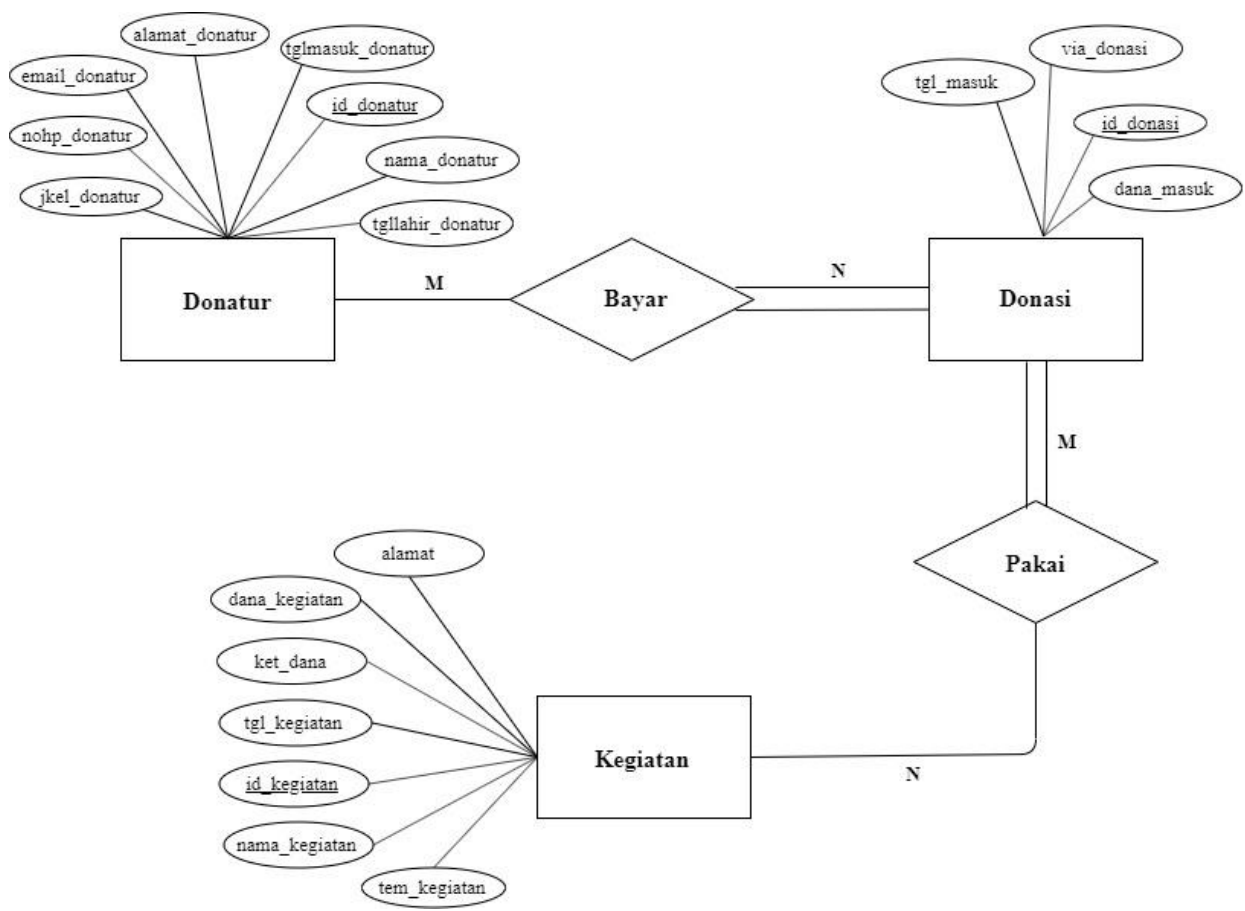

Gambar 3.Entity Relationship Diagram (ERD) 


\section{Pengembangan Sistem}

Berdasarkan proses pengembangan sistem yang digunakan yaitu metode iterative incremental, berikut ini penjelasan dari setiap iterasi yang dilakukan.

1. Iterasi 1

Pada iterasi 1,pembuatan sistem berfokus pada penginputan data-data donasi, donatur, dan kegiatan penyaluran donasi.Pada akhir iterasi 1, dilakukan pengujian sistem kepada pengurus organisasi Gerakan Antasari Sedekah sebaga evaluasi pengembangan aplikasi untuk iterasi berikutnya.

a. Fase Insepsi

Pada fase insepsi, dilakukan pengumpulan requirement untuk membangun sistem administrasi yang didapatkan dari hasil observasi dan wawancara terhadap rutinitas yang berjalan dalam sistem donasi dan penyalurannya.

Tabel 1. Daftar Kebutuhan Fungsionalitas Sistem pada Iterasi 1

\begin{tabular}{|c|c|c|c|}
\hline REQ-ID & Kebutuhan & Rincian Kebutuhan & Deskripsi \\
\hline REQ-01-01 & Kelola Akun Admin & Register & $\begin{array}{l}\text { Proses untuk mendaftar sebagai } \\
\text { adminpada aplikasi }\end{array}$ \\
\hline REQ-01-02 & & Login & $\begin{array}{l}\text { Proses untuk masuk sebagai } \\
\text { adminpada aplikasi }\end{array}$ \\
\hline REQ-01-03 & & Logout & $\begin{array}{l}\text { Proses untuk keluar sebagai } \\
\text { admin dari aplikasi }\end{array}$ \\
\hline REQ-02-01 & Kelola Data Donatur & Tambah Data Donatur & $\begin{array}{l}\text { Proses untuk menambah donatur } \\
\text { pada }\end{array}$ \\
\hline REQ-02-02 & & Lihat Data Donatur & $\begin{array}{l}\text { Proses untuk melihat tabel data } \\
\text { donatur }\end{array}$ \\
\hline REQ-02-03 & & Edit Data Donatur & $\begin{array}{l}\text { Proses untuk mengubah data } \\
\text { donatur }\end{array}$ \\
\hline REQ-02-04 & & Hapus Data Donatur & $\begin{array}{l}\text { Proses untuk menghapus data } \\
\text { donatur }\end{array}$ \\
\hline REQ-02-05 & & Cetak Data Donatur & $\begin{array}{l}\text { Proses untuk mencetak laporan } \\
\text { data donatur }\end{array}$ \\
\hline REQ-03-01 & Kelola Data Donasi & Tambah Data Donasi & $\begin{array}{l}\text { Proses untuk menambah data } \\
\text { donasi }\end{array}$ \\
\hline REQ-03-02 & & Lihat Data Donasi & $\begin{array}{l}\text { Proses untuk melihat tabel data } \\
\text { donasi }\end{array}$ \\
\hline REQ-03-03 & & Edit Data Donasi & $\begin{array}{l}\text { Proses untuk mengubah data } \\
\text { donasi }\end{array}$ \\
\hline REQ-03-04 & & Hapus Data Donasi & $\begin{array}{l}\text { Proses untuk menghapus data } \\
\text { donasi }\end{array}$ \\
\hline REQ-03-05 & & Cetak Data Donasi & $\begin{array}{l}\text { Proses untuk mencetak laporan } \\
\text { data donasi }\end{array}$ \\
\hline REQ-04-01 & $\begin{array}{l}\text { Kelola Data Kegiatan } \\
\text { Penyaluran Donasi }\end{array}$ & $\begin{array}{l}\text { Tambah Data Kegiatan } \\
\text { Penyaluran Donasi }\end{array}$ & $\begin{array}{l}\text { Proses untuk menambah data } \\
\text { kegiatan penyaluran donasi }\end{array}$ \\
\hline REQ-04-02 & & $\begin{array}{l}\text { Lihat Data Kegiatan } \\
\text { Penyaluran Donasi }\end{array}$ & $\begin{array}{l}\text { Proses untuk melihat tabel data } \\
\text { kegiatan penyaluran donasi }\end{array}$ \\
\hline REQ-04-03 & & $\begin{array}{l}\text { Edit Data Kegiatan } \\
\text { Penyaluran Donasi }\end{array}$ & $\begin{array}{l}\text { Proses untuk mengubah data } \\
\text { kegiatan penyaluran donasi }\end{array}$ \\
\hline REQ-04-04 & & $\begin{array}{l}\text { Hapus Data Kegiatan } \\
\text { Penyaluran Donasi }\end{array}$ & $\begin{array}{l}\text { Proses untuk menghapus data } \\
\text { kegiatan penyaluran donasi }\end{array}$ \\
\hline REQ-04-05 & & $\begin{array}{l}\text { Cetak Data Kegiatan } \\
\text { Penyaluran Donasi }\end{array}$ & $\begin{array}{l}\text { Proses untuk mencetak data } \\
\text { kegiatan penyaluran donasi }\end{array}$ \\
\hline
\end{tabular}

b. Fase Elaborasi

Pada fase elaorasi dilakukan analisa dan perancangan sistem untuk aplikasi berupa rancangan diagram rinci berdasarkan requirement yang dihasilkan fase insepsi.

c. Fase Konstruksi

Pada fase konstruksi berfokus pada implementasi aplikasi sesuai dengan requirement yang telah dibuat pada fase sebelumnyadan juga melakukan pengujian unit testing.Seperti pada gambar di bawah ini. 


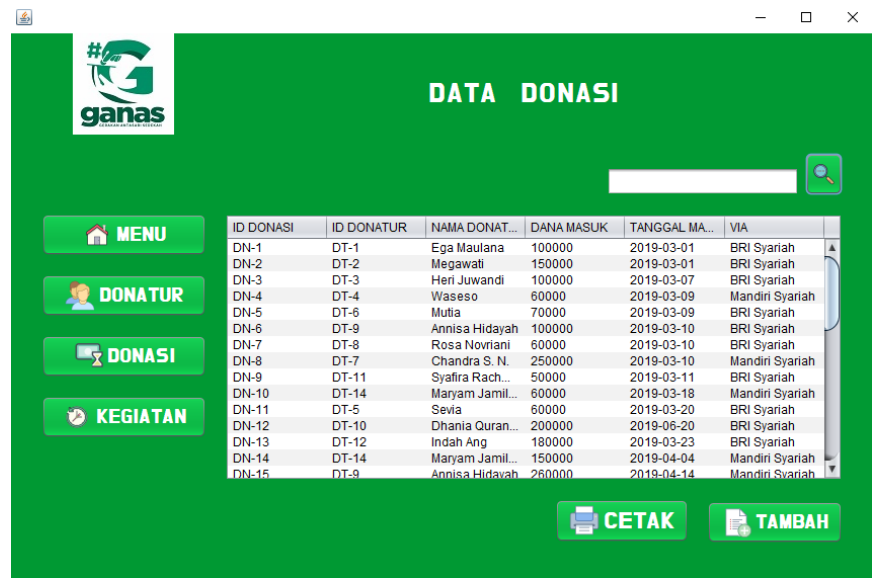

Gambar 4. Tampilan Tabel Data Donasi

\section{d. Fase Transisi}

Pada fase transisi dilakukan pengujian aplikasi kepada pengurus organisasi Gerakan Antasari Sedekah untuk mendapatkan feedback sebagai evaluasi pada iterasi berikutnya. Dari hasil pengamatan dalam pengujian aplikasi pada pengurus, peneliti mendapatkan kesimpulan sebagai berikut:

1) Pengurus membutuhkan fitur cetak bukti penerimaan donasi sebagai bukti ke donatur bahwa donasi telah diterima.

2) Pengurus membutuhkan sistem cetak laporan per periode dan penambahan form laporan keuangan untuk mempermudah perhitungan keuangan pada organisai.

2. Iterasi 2

Pada iterasi 2, requirementsistemberfokus pada fitur laporan dan cetak bukti penerimaan donasi, serta penyederhanaan pada beberapa elemen database.Pada akhir iterasi 2, dilakukan pengujian sistem kepada pengurus organisasi Gerakan Antasari Sedekah sebaga evaluasi pengembangan aplikasi untuk iterasi berikutnya.

a. Fase Insepsi

Pada fase insepsi, dilakukan pengumpulan requirement untuk membangun sistem administrasi yang didapatkan dari hasil iterasi 1 .

Tabel 2. Daftar Kebutuhan Fungsionalitas Sistem pada Iterasi 2

\begin{tabular}{clll}
\hline REQ-ID & \multicolumn{1}{c}{ Kebutuhan } & \multicolumn{1}{c}{ Rincian Kebutuhan } & \multicolumn{1}{c}{ Deskripsi } \\
\hline REQ-03-05 & Kelola Data Donasi & $\begin{array}{l}\text { Cetak Bukti Penerimaan } \\
\text { Donasi }\end{array}$ & $\begin{array}{l}\text { Proses untuk mencetak bukti } \\
\text { penerimaan donasi per donasi }\end{array}$ \\
REQ-05-01 & Kelola Laporan & Cetak Laporan Donasi & $\begin{array}{l}\text { Proses untuk laporan donasi } \\
\text { donasi per periode tertentu }\end{array}$ \\
REQ-05-02 & & Cetak Laporan Donatur & $\begin{array}{l}\text { Proses untuk mencetak laporan } \\
\text { donatur per periode tertentu }\end{array}$ \\
REQ-05-03 & & $\begin{array}{l}\text { Cetak Laporan Kegiatan } \\
\text { Penyaluran Donasi }\end{array}$ & $\begin{array}{l}\text { Proses untuk mencetak data } \\
\text { kegiatan penyaluran donasi }\end{array}$ \\
REQ-05-04 & & Cetak Laporan Keuangan & $\begin{array}{l}\text { Proses untuk mencetak bukti } \\
\text { penerimaan donasi per donasi }\end{array}$ \\
\hline
\end{tabular}

b. Fase Elaborasi

Pada fase elaorasi dilakukan analisa dan perancangan sistem untuk aplikasi berupa rancangan diagram rinci berdasarkan requirement yang dihasilkan fase insepsi. 


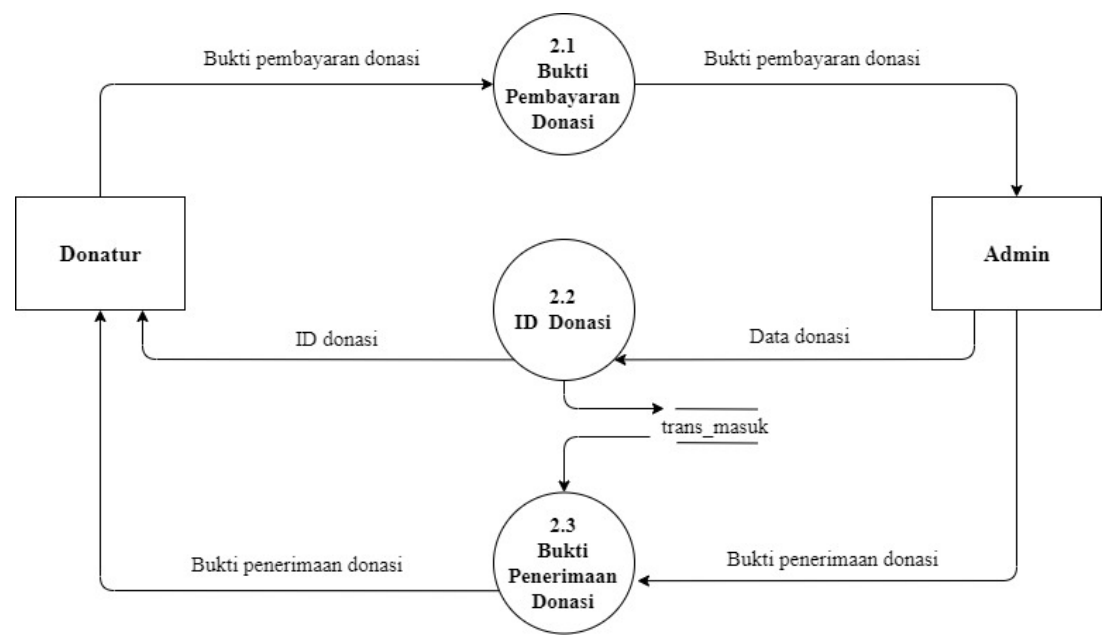

Gambar 5. Diagram Rinci Sistem yang Diusulkan untuk Proses 2

Pada Gambar 5 di atas menunjukan bahwa setelah donatur melakukan donasi dan memberikan bukti pembayaran donasi, maka adminakan memberikan bukti penerimaan donasi.

c. Fase Konstruksi

Pada fase konstruksi berfokus untuk pengembangan sistem sesuai dengan requirement yang telah dibuat pada fase sebelumnya dan juga melakukan pengujian unit testing, systemtesting, usage testing, dan stress testing.Seperti pada gambar di bawah ini.

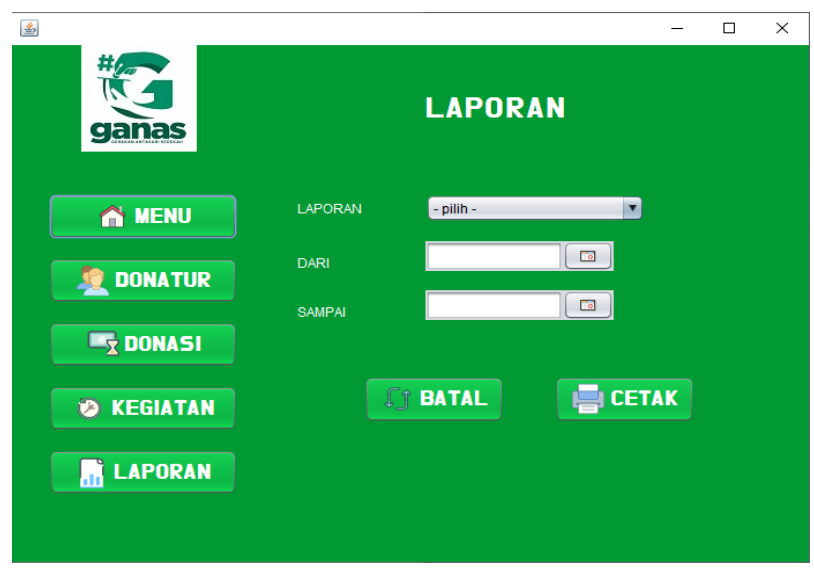

Gambar 6. Tampilan Menu Utama

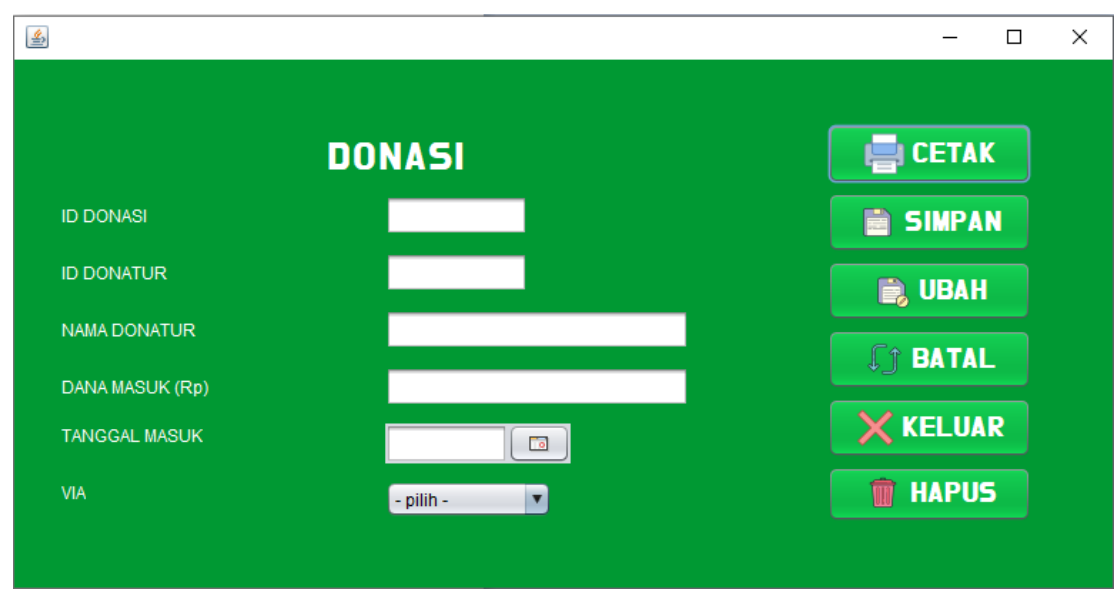

Gambar 7. TampilanForm Donasi 
Pada Gambar 6 menunjukan bahwa fitur cetak laporan telah memiliki menu tersendiri dan memiliki fitur cetak per periode yang dapat ditentukan sesuai kebutuhan.Sedangkan Gambar 7 menunjukan bahwa fitur cetak bukti penerimaan donasi yang dapat digunakan sesuai dengan pemanggilan donasi yang dilakukan.

d. Fase Transisi

Pada fase transisi dilakukan pengujian aplikasi kepada pengurus organisasi Gerakan Antasari Sedekah untuk mendapatkan feedback sebagai evaluasi pada iterasi berikutnya. Dari hasil pengamatan dalam pengujian aplikasi pada pengurus, peneliti mendapatkan kesimpulan sebagai berikut:

1) Pengurus menyarankan untuk mengadakan fitur upload foto untuk mengupload buktibukti pembayaran donasi yang diberikan donatur.

\section{SIMPULAN}

Berdasarkan hasil penelitian yang dilakukan mengenai Implementasi Metode Iterative Incrementalpada Sistem Administrasi Organisasi Gerakan Antasari Sedekah Jakarta, beberapa hal yang dapat disimpulkan adalah sebagai berikut :

1. Dengan terkomputerisasinya sistem administrasi membuat keamanan data-data terjamin dari kehilangan data ataupun kerusakan data karena tersimpannya data-data tersebut dalam sebuah database dengan MySQL.

2. Sistem administrasi ini merupakan sistem berbasis Java yang dikembangkan dengan metode iterative incremental yang bertujuan untuk membantu pengurus dalam mengelola data donasi, data donatur, dan data kegiatan penyaluran donasi.

3. Sistem administrasi ini juga memiliki fitur laporan tersendiri, jadi pengurus dapat mengelola laporan yang dibutuhkan sesuai dengan periode yang dimasukan.

4. Setiap akhir iterasi dilakukan pengujian untuk menghasilkan sistem yang sesuai dengan kebutuhan dan kemampuan user.

\section{DAFTAR PUSTAKA}

Estiana, Pela. (2018). Perancangan sistem informasi pengolahan data sumbangan donatur pada forum kalijambe foundation (FKF) di Desa Kalijambe, Tegal.

Hamali, A. Y., \& Budihastuti, E. S. (2019). Pemahaman Praktis Administrasi, Organisasi, dan Manajemen: Strategi Mengelola Kelangsungan Hidup Organisasi. Jakarta: Prenadamedia Group.

Hidayat, A. T., Gumilang, S. F. S., \& Hasibuan, M. A. (2019). Pengembangan Aplikasi Android "dikampus" Untuk Manajemen Warung Dan Pesanan Menggunakan Metode Iterative Incremental (studi Kasus Layanan Pesan Antar Makanan Untuk Wilayah Kampus Universitas Telkom). Sistem Informasi, 6(2), 8075-8078.

Indrajani. (2011).Perancangan basis data dalam all in 1. Jakarta: PT. Elex Media Komputindo.

Perestroika, Yuris Sucio, dkk. (2018). Pengembangansistem informasi penggalangan donasi pada yayasan gerakan nurani orang tua asuh (GN-OTA) Kabupaten Lumajang. Jurnal Pengembangan Teknologi Informasi dan Ilmu Komputer, 2(5),1834-1835

Rahayu, Ocktia Dwi. (2018). Perancangan sistem administrasi zakat, infaq, dan shodaqoh (ZIS) pada Lembaga Amil Zakat Nahwa Mur Cibinong Bogor berbasis java.

Roger, S. Pressman. (2012).Rekayasa perangkat lunak (pendekatan. praktisi). Edisi 7 : Buku 1. Yogyakarta: Andi.

Shalahuddin, M., \& Rosa, A. S. (2014). Rekayasa perangkat lunak: Terstruktur dan berorientasi objek. Bandung: Informatika.

Soewadji, Jusuf. (2012). Pengantar metodologi peneletian. Jakarta : Mitra Wacana Media.

Susantoputra, Heru, dkk. (2015). Bijak memberdayakan uang plastik. Jakarta: PT Elex Media Komputindo. 